\title{
Viability criteria for the presence of the seagrass Zostera muelleri in Moreton Bay, based on benthic light dose
}

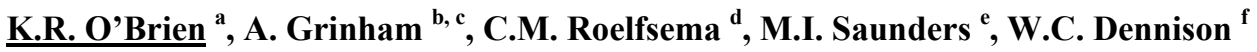 \\ ${ }^{a}$ School of Chemical Engineering, University of Queensland, St Lucia 4072, Brisbane, Queensland, \\ Australia ${ }^{b}$ Centre for Water Futures, The University of Queensland \\ ${ }^{c}$ School of Civil Engineering, The University of Queensland ${ }^{d}$ Biophysical Remote Sensing Group, \\ School of Geography, Planning and Environmental Management, The University of Queensland ${ }^{e}$ Global \\ Change Institute, The University of Queensland ${ }^{f}$ Center for Environmental Science, University of \\ Maryland, Maryland USA
}

Email:k.obrien@uq.edu.au

Seagrasses play an important ecological role in many coastal systems, providing food, habitat and nurseries for many important species, as well as stabilising sediment and controlling sediment nutrient cycling. Due to strong positive feedback between water clarity and seagrass abundance, seagrass decline can be difficult to arrest. Management actions are thus most effective when directed in regions where seagrass loss is likely but has not yet commenced; hence models are required to predict areas at risk of seagrass loss.

Minimum light requirements have been defined for many species in terms of percentage light penetration $\left(\mathrm{I}_{\text {benthic }} / \mathrm{I}_{\text {surface }}\right.$ ), without accounting for seasonal variations in water clarity and irradiance. The purpose of this study was to define minimum benthic light conditions over an annual light cycle required for the presence of the seagrass Z.muelleri (formerly Z.capricorni) in Moreton Bay, Queensland. The relationship between light attenuation coefficient and Secchi depth in Moreton Bay was determined from field data, and used in conjunction with monthly measurements of Secchi depth and four-hourly depth predictions to define benthic light at each sites. Daily benthic light dose was used to determine a range of annual statistics which were then related to presence and absence of Z.muelleri at 204 sites in Moreton Bay. From this analysis, five Z.muelleri viability criteria were defined:

1. average daily benthic light dose $\geq 9 \mathrm{~mol}$ quanta $\mathrm{m}^{-2} \mathrm{~d}^{-1}$ (i.e. $25 \%$ of the average daily surface light dose);

2. average light penetration $\geq 25 \%$ of incident light;

3. average Secchi depth $\geq$ average water depth;

4. more than $80 \%$ of days per year with light penetration $\geq 15 \%$;

5. fewer than 80 consecutive days with light penetration $\leq 15 \%$.

In all cases, Z.muelleri was absent in $93 \%$ of sites where the viability criteria were not met, suggesting that each of these measures is likely to have some merit in defining what changes in benthic light conditions could lead to loss of Z.muelleri in Moreton Bay. In contrast, Z.muelleri was present in slightly less than $50 \%$ of all sites where the viability criteria were met; this implies that benthic light criteria define necessary but not sufficient conditions for Z.muelleri presence in Moreton Bay.

The first four criteria are integrated annual statistics, and so could be used to assess the risk of Z.muelleri loss from long-term changes such as sea level rise and eutrophication. However the fifth index also has the potential to assess the risk of Z.muelleri loss from turbidity pulses such as flood or dredging plumes.

Further development and validation of the Z.muelleri viability criteria are required before they can be applied to define seagrass risk maps for Moreton Bay. This will require investigation of factors affecting the presence of Z.muelleri at sites where the viability criteria was not met, validation of the model through application to periods of historical seagrass loss, and extension to other species.

Overall, these results indicate that a range of different models are required to assess seagrass risk even for a single species within a single system, because seagrass viability depends on both long-term average and short-term variations in benthic light availability.

Keywords: Benthic irradiance, seagrass, light limitation, Secchi depth, Z.muelleri 


\section{INTRODUCTION}

Seagrasses play an important role in coastal ecosystems, through providing habitat and food for marine animals, nutrient recycling and sediment trapping and stabilization (Dennison et al. 1993, Orth et al. 2006). However seagrass distribution has been declining worldwide in recent decades, due to multiple and interacting stressors including outbreaks of disease, declining water clarity, physical disturbance, extreme flood events, dredging, destructive fishing and invasive species (Abal and Dennison 1996, Duarte 2002, Orth et al. 2006, Waycott et al. 2009). Increased human population size and global climate change will further exacerbate these threats.

Benthic light availability plays a major role in seagrass distribution and abundance (Dennison 1987). Consequently, seagrass decline is strongly affected by activities in adjacent catchments which decrease water clarity through high sediment and nutrient run-off to coastal waterways (Abal and Dennison 1996, Orth et al. 2006). The stabilization of sediments by seagrass creates a positive feedback loop, whereby reductions in benthic light causing seagrass loss result in greater sediment resuspension and hence further reductions in benthic light (e.g. Dennison and Abal 1999, de Boer 2007). As a result, remedial action is generally not effective once seagrass decline has commenced (Orth et al. 2006). Hence, addressing the ongoing loss of seagrass and their associated ecosystem services requires the development of models which can identify areas at risk of seagrass loss, which can then be targeted for management actions (Duarte 2002).

Minimum benthic light requirements have been quantified for a number of seagrass species, and these conditions can be converted directly to maximum depth or critical light attenuation coefficient, and then to associated water quality parameters chlorophyll $a$ and turbidity (e.g. Dennison 1987, Dennison et al. 1993, Abal and Dennison 1996, Longstaff and Dennison 1999, Lee et al. 2007). However, water quality parameters and light attenuation vary both seasonally and with periodic events such as floods and sediment resuspension, and tolerance to periods of light reduction vary between species (Longstaff and Dennison 1999). These intermittent disturbances to the benthic light regime are not captured using annual mean data for water clarity and irradiance, and thus more detailed models are required to predict risk to seagrass by extreme events, such as floods.

The purpose of this study was to define criteria for seagrass presence based on benthic light conditions, which is a critical step in identifying areas at risk of seagrass loss. Viability criteria based on benthic irradiance over an annual cycle were investigated for the seagrass species Zostera muelleri (formerly Zostera capricorni) in Moreton Bay, Queensland. This species was chosen because it is the dominant species in Moreton Bay, and was less subject to seasonal variation and grazing pressure than other recorded species (Abal et al. 1994, Abal and Dennison 1996). The presence/absence of Z.muelleri at 204 positions in the study area was determined from Roelfsema et al. (2009), and compared with a range of benthic light statistics at each site over the previous year. The results provide

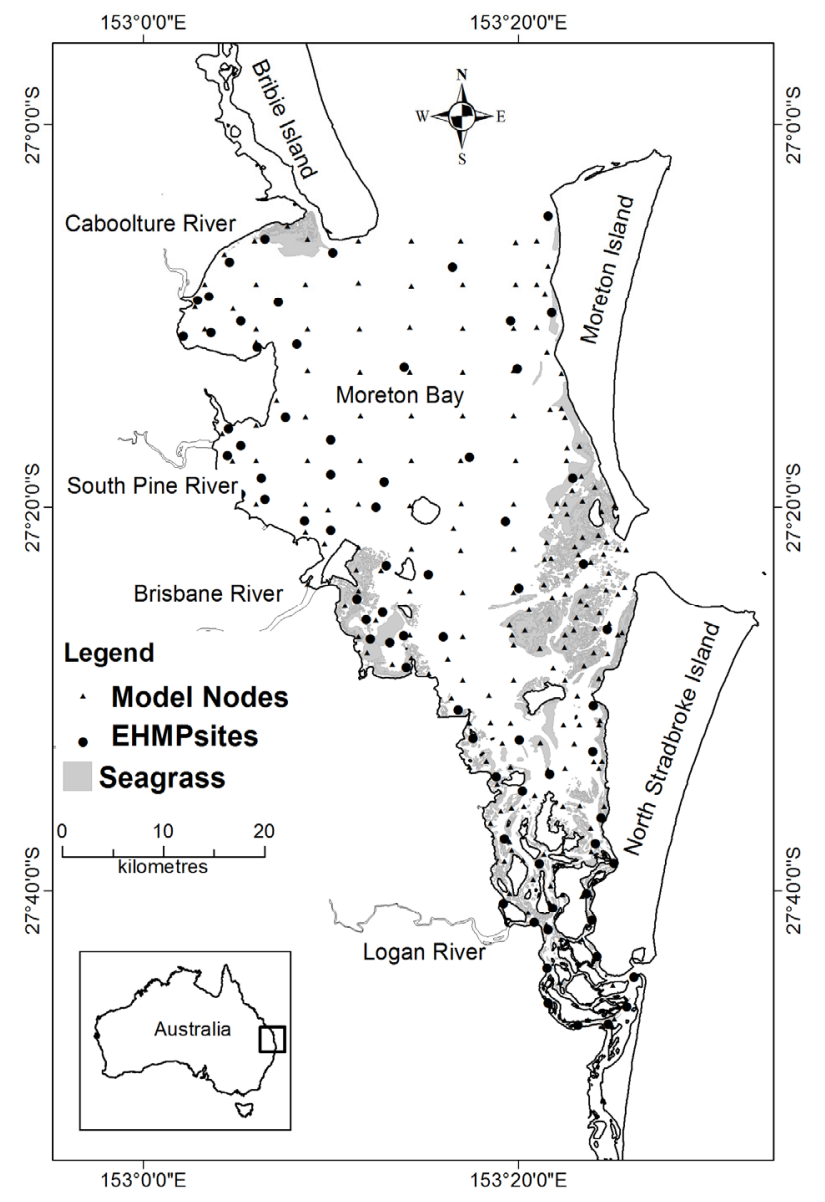

Figure 1: Moreton Bay study site, with location of the Ecological Health Monitoring Program (EHMP) monthly Secchi depth sampling sites and the model node positions. Seagrass areas resulted from 2004 seagrass mapping (Roelfsema et al 2009). 
preliminary viability criteria guidelines for defining where Z.muelleri presence in Moreton Bay is limited by light availability, and which areas are at risk of seagrass loss due to increase in either depth or light attenuation coefficient, or turbidity pulses.

\section{STUDY SITE - MORETON BAY}

Moreton Bay $\left(27^{\circ} 15^{\prime} \mathrm{S}, 153^{\circ} 15^{\prime} \mathrm{E}\right)$, is a large estuary on which Brisbane, is situated (Queensland, Australia). Its catchment is home to 2 million people and it is one of the five fastest growing urban regions in the developed world. The bay is a partially enclosed area and is protected from Pacific Ocean by a chain of three islands: Moreton Island in the north, North and South Stradbroke Islands in the south.

In Moreton Bay freshwater input occurs via six major inland streams and rivers, and oceanic exchange occurs primarily through a $16 \mathrm{~km}$ wide opening to the north (North Passage) and two smaller openings to the east and south (Fig. 1). It has a total surface area of about $1650 \mathrm{~km}^{2}$ with a total catchment area of $22,000 \mathrm{~km}^{2}$ (Douglas et al. 2003). The estuary is generally shallow with an average depth of $6.4 \mathrm{~m}$ and maximum depth of $30 \mathrm{~m}$ in the eastern bay. The intertidal and subtidal shallow banks of the Moreton Bay have large areas of seagrass beds which consist of 7 species of seagrass (Z.muelleri, Cymodocea rotundata, Holophila ovalis, Holophila spinulosa, Holophila decipiens, Syringodium sp. and Holodule uninervis). The seagrasses form an important nursery ground, and provide a source of food for fish, invertebrates, turtles and dugongs. It has a semi-diurnal tidal regime with a range of 1.5-2 $\mathrm{m}$. The Moreton Bay region has a subtropical climate, with hot, wet summers and dry, sunny winters.

\section{BENTHIC LIGHT CALCULATION AND Z.MUELLERI PRESENCE AND ABSENCE}

To calculate the daily benthic irradiance throughout Moreton Bay, 204 node positions were selected. 104 nodes were uniformly distributed throughout the bay, and an additional 100 nodes were located in regions of shallow or variable depth. At each of these node positions, daily benthic light was calculated using monthly Secchi depth data from the Environmental Health Monitoring Program (EHMP 2004), 4-hourly water depth predicted from the Moreton Bay Receiving Water Quality Model version 2 (RWQM) (McAlister et al. 2005) and daily radiation measured by the Bureau of Meteorology at the western edge of the bay. The presence or absence of Z.muelleri was determined at each node position, based on maps of seagrass distribution in Moreton Bay generated using remote sensing with field validation in July-August 2004 (Roelfsema et al. 2009). A range of benthic light statistics for the preceding year were then compared at sites where Z.muelleri was present or absent. The impacts of self-shading and epiphyte shading on benthic irradiance were neglected.

\subsection{Daily benthic light}

Daily benthic light (i.e. photosynthetically active radiation PAR) $I$, mol quanta $\mathrm{m}^{-2} \mathrm{~h}^{-1}$, was calculated at node position $n$ and time $t$ using the Beer-Lambert function (Kirk 1994):

$$
I(n, t)=I_{\text {surface }}(t) e^{-K_{d}(n, t) z(n, t)}
$$

where $I_{\text {surface }}(t)$, mol quanta $\mathrm{m}^{-2} \mathrm{~h}^{-1}$ is the incident PAR, $z(n, t)$ is the depth, $\mathrm{m}$, at position $\mathrm{n}$ and time $\mathrm{t}$ and $K_{d}(n, t), \mathrm{m}^{-1}$ is the vertical light extinction coefficient, which was assumed to be constant over depth. The hourly depth at each node position was determined using a Matlab ${ }^{\mathrm{TM}}$ spline interpolation of 4-hourly depth predictions by the Moreton Bay RWQM Version 2 (McAlister et al. 2005). Since depth data was not available for the full study period, depth for January-July 2003 was used to represent the depth for the period January-July 2004. The incident irradiance $I_{\text {surface }}(t)$ was assumed to be constant across the bay, and was determined from the maximum hourly surface PAR ${ }_{\max }^{\text {incident }}$, mol quanta $\mathrm{m}^{-2} \mathrm{~h}^{-1}$, assuming a half-sinusoid daily regime (Chapra 1997):

$$
\begin{array}{ll}
I_{\text {surface }}(t)=I_{\max }^{\text {incident }} \operatorname{Sin}\left(\pi \frac{t-t_{0}}{t_{f}-t_{0}}\right) & \text { if } t_{0}<t<t_{f} \\
I_{\text {surface }}(t)=0 & \text { elsewhere }
\end{array}
$$

where $t_{f}$ and $t_{0}$ are respectively time of sunset and sunrise in hours, and $I_{\max }^{\text {incident }}$ was determined from the daily total surface PAR dose $\bar{Q}_{\text {daily }}^{\text {incident }}$, mol quanta $\mathrm{m}^{-2}$ (Chapra 1997): 


$$
I_{\max }^{\text {incident }}=\bar{Q}_{\text {daily }}^{\text {incident }} \frac{\pi / 2}{t_{f}-t_{o}}
$$

$\bar{Q}_{\text {daily }}^{\text {incident }}$

$Q_{\text {daily }}$ was determined from daily global surface exposure (GSE) dose (MJ m ${ }^{-2}$ ) using the relationship found by Grinham (2007) in South-East Queensland:

$$
\bar{Q}_{\text {daily }}{ }^{\text {incident }}=G S E / 0.5639 \text { MJ }^{\text {mol }} \text { quanta }^{-1}
$$

where GSE is the total amount of solar energy falling on a horizontal surface in one day, monitored daily by the Commonwealth Bureau of Meteorology on the western edge of the bay. For days where global surface exposure data was missing, average values of the adjacent days were used.

\subsection{Light attenuation coefficient}

Light attenuation coefficient $K_{d}, m^{-1}$, was determined from Secchi depth data measured at Ecosystem Health Monitoring Program (EHMP) sites within the bay, using a Matlab ${ }^{\mathrm{TM}}$ spline procedure to interpolate from monthly to daily time step. For each model node position, the Secchi depth was assumed equal to that at the nearest EHMP site location. $K_{d}$ was calculated from Secchi depth (e.g. Chapra 1997):

$K_{d}=\lambda / z_{S D}$

where $z_{S D}$ is the Secchi depth, $\mathrm{m}$, and $\lambda$ is a constant. The value of $\lambda$ in Moreton Bay was determined from a linear regression of Secchi depth and $K_{d}$ data, from measurements made in Deception Bay in June 2007 and a bay-wide survey in May 2008. The light attenuation coefficient $K_{d}$ was calculated from the PAR measured at two different depths at each site, using a LiCor 1400 light sensor lowered on a pole marked with depth measurements:

$$
K_{d}=\ln \left[\frac{I\left(z_{1}\right)}{I\left(z_{2}\right)}\right] /\left[z_{2}-z_{1}\right]
$$

where $I\left(z_{1}\right)$ is the irradiance, $\mu \mathrm{mol}$ quanta $\mathrm{m}^{-2} \mathrm{~s}^{-1}$, measured at depth $z_{1}, \mathrm{~m}$, and $I\left(z_{2}\right)$ is the irradiance measured at depth $z_{2}$.

\subsection{Measurement and prediction of Z.muelleri presence and absence}

The presence or absence of Z.muelleri at each node position was determined for the July-August 2004 Moreton Bay seagrass distribution survey using ARC GIS software. Annual average benthic light statistics (e.g. minimum, maximum and mean daily benthic light dose and \% light penetration) were calculated from daily benthic light dose at each model node position for the year prior to the seagrass survey, i.e. 1 August 2003 to 31 July 2004.

Benthic light penetration was defined as the ratio of daily surface light dose to daily benthic light dose, i.e. $\mathrm{I}_{\text {benthic }} / \mathrm{I}_{\text {surface }}$. The total number of days and the maximum number of consecutive days on which light penetration was less than 5, 10, 1520 and $25 \%$, and on which daily benthic light dose was less than $5,10,15$ 20 and $25 \%$ of the average daily incident light dose $\left(36\right.$ mol quanta $\left.\mathrm{m}^{-2} \mathrm{~d}^{-1}\right)$ were determined for each node position. Box plots of each of these indicators were generated and compared between sites where Z.muelleri was present, and where Z.muelleri was absent. "Viability criteria" were then identified, as critical values which differentiated between Z.muelleri presence and absence.

Annual benthic light statistics were also compared with simpler estimates calculated from annual averages of depth, incident light and light attenuation coefficient to determine the value in using criteria based on annual average data, rather than the more time- and data-intensive integrated hourly benthic light data.

\section{RESULTS}

The relationship between light attenuation coefficient $K_{d}$ and Secchi depth $z_{S D}$ in Moreton Bay was found to be $\lambda=1.6$ (Fig. $2, \mathrm{R}^{2}=0.97$ ):

$K_{d}=1.6 / z_{S D}$

There was some variability between the two datasets used to derive Eqn $7 ; \lambda=1.40\left(\mathrm{r}^{2}=0.90, \mathrm{p}<0.05\right)$ for measurements made in Deception Bay in June 2007, and $\lambda=1.62\left(\mathrm{r}^{2}=0.99, \mathrm{p}<0.05\right)$ for bay-wide 
measurements made in May 2008, which indicates that the value of $\lambda$ can vary around the bay. Hence measuring light profiles and determining $K_{d}$ from Eqn 7 would be preferable to measuring Secchi depth in routine monitoring. Application of Eqn 7 to the predicted annual average light requirements of Zostera

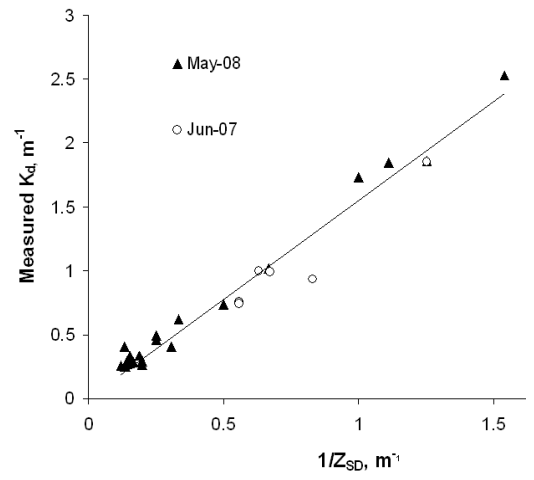

Figure 2: Light attenuation coefficient $K_{d}$ vs secchi depth in Moreton Bay muelleri (Dennison 1987), $K_{d} z \leq 1.6$, would thus translate to a maximum depth range equivalent to the Secchi depth.

Five Z.muelleri viability criteria were defined as those annual benthic light statistics which provided the greatest differentiation between presence and absence sites (Table 1). Three of these criteria were based on annual integrated averages: average daily benthic light dose $\geq 9$ mol quanta $\mathrm{m}^{-2}$ $\mathrm{d}^{-1}$ (which was $25 \%$ of the annual average incident light dose, 36 mol quanta $\mathrm{m}^{-2} \mathrm{~d}^{-1}$ ); average incident light penetration $\geq 25 \%$; and average Secchi depth $\geq$ average water depth. The other two criteria were based on duration of minimum light dose: more than $80 \%$ of total days with light penetration $\geq 15 \%$, and fewer than 80 consecutive days with light penetration $\leq 15 \%$.

The predicted minimum light requirement for Z. muelleri viability varied from $15 \%$ of incident light when using daily benthic light dose as an indicator, to $25 \%$ of incident light for annual average benthic light dose. The former provide an estimate of the duration that Z.muelleri can withstand reduced light availability (Table 1). All five Z.muelleri viability criteria worked well in defining regions where Z.muelleri presence was limited by light; of the node sites where Z.muelleri was present, $82 \%$ met all five Z.muelleri viability criteria (Table 1). False negatives (i.e. presence of Z.muelleri at sites where the viability criteria were not met) occurred at the same 8 sites for all five criteria. The calculated average daily benthic light at these sites was $2-6 \mathrm{~mol}$ quanta $\mathrm{m}^{-2} \mathrm{~d}^{-1}$, which may underestimate the true value, due to the uncertainties associated with the temporal and spatial interpolation of seagrass, depth and Secchi depth information used to estimate benthic light dose. Difference in predictions between the five viability criteria only occurred for sites where Z.muelleri was absent.

Table 1: For each of the five Z.muelleri viability criteria, the number of observations with Z.muelleri present and absent are defined for node positions where the viability criteria are satisfied, and for node positions where the criteria are not satisfied.

\begin{tabular}{|c|c|c|c|c|}
\hline \multirow[b]{2}{*}{ Z.muelleri viability criteria } & \multicolumn{2}{|c|}{$\begin{array}{l}\text { Number of observations } \\
\text { where } Z \text {.muelleri viability } \\
\text { criteria satisfied }\end{array}$} & \multicolumn{2}{|c|}{$\begin{array}{l}\text { Number of observations } \\
\text { where } Z . m u e l l e r i \text { viability } \\
\text { criteria } N O T \text { satisfied }\end{array}$} \\
\hline & $\begin{array}{l}\text { Z.muelleri } \\
\text { present }\end{array}$ & $\begin{array}{l}\text { Z.muelleri } \\
\text { absent }\end{array}$ & $\begin{array}{l}\text { Z.muelleri } \\
\text { present }\end{array}$ & $\begin{array}{l}\text { Z.muelleri } \\
\text { absent }\end{array}$ \\
\hline $\begin{array}{l}\text { Average daily benthic light dose } \\
\bar{I}_{\text {benthic }} \geq 9 \text { mol quanta } \mathrm{m}^{-2} \mathrm{~d}^{-1}\end{array}$ & 36 & 40 & 8 & 113 \\
\hline $\begin{array}{l}\text { Average daily benthic light penetration } \\
\left(\overline{\frac{I_{\text {benthic }}}{I_{\text {sufface }}}}\right)=\overline{e^{-K d z}} \geq 0.25\end{array}$ & 36 & 42 & 8 & 111 \\
\hline Average Secchi depth $\geq$ Average water depth & 36 & 49 & 8 & 104 \\
\hline $\begin{array}{l}\text { Benthic light penetration } \\
\frac{I_{\text {benthic }}}{I_{\text {sufface }}}=e^{-K_{d} z} \geq 0.15 \text { for more than } 80 \% \text { of days per year }\end{array}$ & 36 & 45 & 8 & 108 \\
\hline $\begin{array}{l}\text { Benthic light penetration } \\
\frac{I_{\text {benthic }}}{I_{\text {surface }}}=e^{-K_{d} z} \leq 0.15 \text { for less than } 80 \text { consecutive days }\end{array}$ & 36 & 45 & 8 & 108 \\
\hline
\end{tabular}


Annual average benthic light calculated from integrating Eqn 1 was slightly higher than the benthic light dose calculated by substituting annual average incident light, $\bar{I}_{0}$, light attenuation coefficient depth, $\bar{K}_{d}$, and depth $\bar{z}$ into Eqn 1 (Fig. 3a). Similarly the percentage benthic light penetration, $e^{-K_{d} z}$, calculated from integrating data over time at each node position was only slightly higher than $e^{-\bar{K}_{d} \bar{z}}$ (Fig. 3b). The results indicated that benthic light dose and penetration calculated from annual averages $\bar{I}_{0}, \bar{K}_{d}$ and $\bar{z}$ produced a reasonable estimate of annual average benthic light dose and light penetration in Moreton Bay (Fig. 3).

\section{DISCUSSION AND CONCLUSIONS}

The viability criteria defined here were quite effective in predicting where Z.muelleri would not grow; this species was absent at $93 \%$ of all sites where the viability criteria were not satisfied (Table 1). In contrast, Z.muelleri was observed at less than $50 \%$ of node sites where the viability criteria were met; hence although light is a limiting factor for seagrass presence, other factors such as nutrient availability, substrate and current velocity play a role in determining seagrass distribution. In particular, the absence of Z.muelleri in suitable regions may be due to competitive interactions with other seagrass species. Further investigation should be conducted on individual sites to identify whether predictions failed due to limitations of the indicator, or due to the uncertainty associated with assumptions and interpolations made in calculating benthic light dose.

The major difference between the criteria was not their prediction ability, but the ease of application and potential use in defining regions at risk of Z.muelleri loss. For example, the comparison of Secchi depth with average water depth will be more feasible than estimating daily benthic irradiance in systems where data and modelling resources are limited. The criteria based on annual averages and total days per year above a critical benthic light threshold will be useful in predicting areas at risk of Z.muelleri loss due to long-term changes in depth and water clarity (e.g. due to sea level rise and eutrophication). In contrast, the maximum number of consecutive days below a critical light threshold would be the best criteria to assess the risk of Z.muelleri loss due to turbidity pulse events, such as flood or dredge plumes. Overall, these results indicate that a range of different models are required to assess the risk of seagrass loss due to different impacts even for a single species within a single system, because seagrass viability depends on both long-term average benthic light availability and short-term variations in light.

The similarity between results for seagrass presence calculated from annual averages $\bar{I}_{0}, \bar{K}_{d}$ and $\bar{z}$ and from integrated daily values suggests that the interaction of the tidal and light cycles has a minimal effect in Moreton Bay, possibly due to the relatively low tidal range $(1.5-2 \mathrm{~m})$, and the relatively rapid daily progression of high and low tide times. At sites where the optical tidal range is high (due to very high tidal range and/or high light attenuation coefficient) and tidal progression is slow, the integrated averages of daily benthic light dose and penetration will deviate markedly from estimates using annual average data. This is because high tide may occur at the same time of day for a substantial period if the tidal progression is slow, which would have a major effect on benthic light if there is a large difference in optical depth between high and low tides.

The success of the five viability criteria defined in this study in predicting seagrass absence is promising. The prediction of seagrass absence in regions were seagrass was previously recorded is critical for 
management because effective prediction of where seagrass cannot survive is crucial for defining regions vulnerable to seagrass loss. Models of seagrass risk can also reduce costs associated with seagrass monitoring by enabling field sampling to target areas of interest and concern. The results here provide preliminary guidelines for one species only, but represent a starting point for the development of multispecies viability model for seagrass in Moreton Bay. Future studies should incorporate more sophisticated spatial interpolation of light attenuation coefficient and depth data from the new Moreton Bay Receiving Water Quality model, investigate the use of statistical models for assessing viability criteria, and employ statistical models to validate viability criteria against mapped seagrass distribution.

\section{ACKNOWLEDGMENTS}

We thank South East Queensland Healthy Waterways Partnership for providing monitoring data for this project, Tony Howes for retrieving RWQMv2 predictions and Graeme Curwen for assistance with GIS Figure 1. Maxime Burgio and Florent Guignard assisted with data collection and processing.

\section{REFERENCES}

Abal, E.G. and Dennison, W.C. (1996). Seagrass depth range and water quality in southern Moreton Bay, Queensland, Australia, Marine and Freshwater Research 47 (1996), pp. 763-771.

Abal, E. G., Loneragan, N., Bowen, P., Perry, C. J., Udy, J. W., and Dennison, W. C. (1994). Physiological and morphological responses of the seagrass Zostera capricorni Aschers. to light intensity. Journal of

Experimental Marine Biology and Ecology 178, 113-29.

Chapra S. C. (1997). Surface Water-Quality Modeling. WCB McGraw-Hill. Boston.

Boer WF. (2007). Seagrass-sediment interactions, positive feedbacks and critical thresholds for occurrence: a review. Hydrobiologia 591: 5-24.

Dennison, W.C. (1987). Effects of light on seagrass photosynthesis, growth and depth distribution. Aquatic Botany 27, 15-26.

Dennison W.C. and Abal E.G. 1999. Moreton Bay: A scientific basis for the Healthy Waterways Campaign. South East Queensland Regional Water Quality Management Strategy. Brisbane.

Dennison, W. C., R. J. Orth, K. A. Moore, J. C. Stevenson, V. Carter, S. Kollar, P. W. Bergstrom, and R. A. Batiuk. (1993). Assessing water quality with submersed aquatic vegetation. BioScience 43:86-94.

Douglas, G., M. Palmer, and G. Caitcheon. 2003. The provenance of sediments in Moreton Bay, Australia: a synthesis of major, trace element and $\mathrm{Sr}-\mathrm{Nd}-\mathrm{Pb}$ isotopic geochemistry, modeling and landscape. Hydrobiologia. 494: 145-152.

Duarte, C. M. (2002). The future of seagrass meadows. Environmental Conservation 29:192-206.

EHMP. (2004). Ecosystem Health Monitoring Program 2002-2003 Annual Technical Report. Moreton Bay Waterways and Catchments Partnership. Brisbane.

Grinham, A.R. (2007). Downstream effects of land use on shallow-water benthic microalgal communities in Moreton Bay, Australia and Marovo Lagoon, Solomon Islands PhD Thesis, University of Queensland, Brisbane, Australia.

Kirk J.T.O. (1994). Light and photosynthesis in aquatic ecosystems. Cambridge: Cambridge University Press.

Lee, K.-S., Park, S.R., Kim, Y.K. (2007) Effects of irradiance, temperature, and nutrients on growth dynamics of seagrasses: A review. Journal of Experimental Marine Biology and Ecology 350:144-175.

Longstaff, B. J. and Dennison, W. C.. (1999). Seagrass survival during pulsed turbidity events: The effects of light deprivation on the seagrasses Halodule pinifolia and Halophila ovalis. Aquatic Botany 65:105-121.

McAlister, T., Beling, E. and Barry, M. (2005). Moreton Bay Water Quality Improvement Plan - Water Quality Modelling: Final Report. Moreton Bay Waterways and Catchments Partnership, Brisbane, Australia.

Orth R.J., Carruthers, T.J.B., Dennison, W.C., Duarte, C.M., Fourqurean J.W., Heck, K.L., Hughes, A.R., Kendrick, G.A., Kenworthy, W.J., Olyarnik, S., Short, F.T., Waycott, M., and Williams, S.L. (2006). A global crisis for seagrass ecosystems. Bioscience 56: 987-996.

Roelfsema, C. M., Phinn, S. R., Udy, N. and Maxwell, P. (2009). An Integrated Field and Remote Sensing Approach for Mapping Seagrass Cover, Moreton Bay, Australia, Journal of Spatial Science, vol. 54 (1): 45-62.

Waycott, M., Duarte, C. M., Carruthers, T. J. B., Orth, R. J., Dennison, W. C., Olyarnik, S., Calladine, A., Fourqurean, J. W., Heck, K. L., Hughes, A. R., Kendrick, G. A., Kenworthy, W. J., Short. F. T., Williams, S. L. (2009) Accelerating loss of seagrasses across the globe threatens coastal ecosystems. Proceedings of the National Academy of Sciences 106:12377-12381. 